УДК 69:001.89

DOI https://doi.org/10.32782/2664-0406.2021.39.3

\title{
Григоровський П.Є.
}

д.т.н., с.н.с.,

ДП «Науково-дослідний інститут будівельного виробництва», м. Київ

\section{Чуканова Н.П.}

завідувачка відділу обстеження, комплексної діагностики та експериментального проектування будівель і споруд,

ДП «Науково-дослідний інститут будівельного виробництва», м. Київ

\section{Мурасьова О.В.}

заступник завідувача відділу,

ДП «Науково-дослідний інститут будівельного виробництва», м. Київ

\section{Наріжний B.В.}

аспірант,

Київський національний університет будівництва і архітектури, м. Київ; інженер 1 категорії,

ДП «Науково-дослідний інститут будівельного виробництва», м. Київ

\section{АНАЛІЗ ЕФЕКТИВНОСТІ ВПРОВАДЖЕННЯ УНІФІКОВАНИХ СИСТЕМ МОНІТОРИНГУ БУДІВЕЛЬ НА ЕТАПАХ БУДІВНИЦТВА ТА ЕКСПЛУАТАЦІї}

\begin{abstract}
Анотащія. У процесі експлуатацї будівель впровадження систем інструментального моніторингу останнім часом значно поширюється. Упровадження иих систем стало необхідністю в умовах стрімкого розвитку використання інформаційних систем у будівельній галузі України. Досить вивченим є питання впровадження таких систем як на етапі будівництва, так і на етапі експлуатації будівлі. Подальшим кроком для вдосконалення організації виконання технологічних рішень інструментального моніторингу в будівництві та підвищення його техніко-економічної складової,, , зокрема, вивчення організаційно-технологічних процесів з урахуванням поєднання та інтеграцї систем моніторингу протягом життєвого циклу будівель на етапах будівництва та експлуатації будівлі або окремої конструкиіі.

Виконання та впровадження саме однієі системи моніторингу, яка буде використовуватись $i$ під час будівнищтва, $i$ під час експлуатащї будівлі, $є$ досить актуальним з урахуванням впровадження будівельних інформащійних технологій (ВIM) з метою моделювання життєвого ииклу будівель та прогнозування їх фізичного зносу. Уніфікація виробів супроводжується виявленням оптимальних конструкторсько-технологічних рішень та типізацією шляхом комбінування (поєднанням) найбільш вдалих конструкторсько-технологічних рішень. Перспективним є розроблення рішень із упровадження систем моніторингу на етапі реконструкції будівлі завдяки виконанню певних технологічних прощесів, можливих лише під час виконання операцій, пов'язаних із втручання в основні, несучі елементи та конструкиї. Реконструкцію та всі різновиди ремонтних робіт виконують фактично на етаnі експлуатації. Уніфікація виробів супроводжується виявленням оптимальних конструкторсько-технологічних рішень та типізачією шляхом комбінування (поєднанням) найбільш вдалих конструкторсько-технологічних рішень. Питання інтеграції систем моніторингу технологічних процесів на етапі будівництва в системи моніторингу на етапі експлуатації потребує детального вивчення.
\end{abstract}

Ключові слова: система моніторингу, організаційно-технологічні процеси, життєвий цикл будівель, будівельні інформачійні технологї. 
Постановка проблеми. Питання інтеграції систем моніторингу технологічних процесів під час будівництва в системи моніторингу під час експлуатації залишається відкритим. На нашу думку, вивчення та вирішення даного завдання сприятиме підвищенню ефективності виконання будівельних процесів та підвищенню економічних показників вартості будівництва. На даний час досить вивчені методи та способи використання даних систем порізно. Відкритою проблемою залишається інтеграція системи між собою. Варто зауважити, що науково-технічні засоби мають достатній технічний апарат та інформаційно-технічні рішення для виконання поставленої задачі.

Аналіз останніх досліджень. Діагностика будівель на різних етапах життєвого циклу (будівництва, експлуатації, реконструкції, зняття з експлуатації) досить вивчена. У технічній літературі докладно описано впровадження даних систем. Науково-технічні бази постійно поновлюються та доповнюються новими технічними рішеннями та пропозиціями з реалізаціями систем моніторингу. Найбільш відпрацьованими з методологічної точки зору є системи моніторингу саме на етапі експлуатації. Методи інтеграції систем між різними етапами життєвого циклу будівель не розповсюджені в практиці науково-технічного супроводу забезпечення їх технічного стану. Причиною такого стану речей є різні власники будівлі на етапах будівництва та експлуатації, економічні інтереси яких не збігаються та часто є протилежними. Якщо будівельна організація прагне зменшити будівельні витрати, то власник будівлі на етапі експлуатації прагне продовжити етап експлуатації.

Мета роботи. Аналіз найбільш ефективних способів інтеграції систем моніторингу під час будівництва в системи моніторингу подальшої експлуатації будівель. Розглянути актуальність та техніко-економічну доцільність використання даних систем у практиці виконання будівельних процесів. Систематизувати актуальну інформацію поєднання технічних рішень впровадження даних систем. Розглянути організаційно-технологічні рішення, реалізації прогресивних методів модернізації наявних систем моніторингу будівельних процесів для впровадження їх у моніторинг експлуатуючої будівлі.

Виклад основного матеріалу. Основною метою систем моніторингу будівель є своєчасне виявлення технічних змін будівлі чи конструкції, зокрема для їх подальшого контролю. Для кращого розуміння алгоритмів поєднання зазначених систем на різних етапах контролю технічного стану будівлі їх необхідно розділити, визначити необхідні технічні засоби та параметри моніторингу, методи та способи оптимального використання прийнятих систем, технічну можливість їх реалізації та подальшого використання. На табл. 1 приведено етапи життєвого циклу будівлі, основні параметри контролю (моніторингу) для кожного з етапів та типові прилади, які, як правило, використовують для реєстрації вказаних параметрів.

Слід зауважити, що використання деяких технічних засобів на різних етапах будівництва $\epsilon$ або неможливим, або економічно недоцільним, тому в першу чергу необхідно визначити найбільш уніфіковані параметри контролю для різних етапів та мету їх реалізації.

у загальному технічному розумінні «уніфікація» (від лат. unus - один, лат. facio - роблю; об'єднання) пояснюється як найпоширеніший і ефективний метод стандартизації, який передбачає приведення об'єктів до однотипності на основі встановлення раціонального числа їх різновидів [1]. Уніфікація сприяє розвиткові спеціалізації виробництва, комплексної механізації та автоматизації.

Уніфікація полягає у виборі оптимальної кількості або в раціональному скороченні числа типів, видів, параметрів і розмірів об'єктів однакового чи близького функційного призначення. Уніфікація спрямована на зменшення числа різновидів об’єктів шляхом комбінування двох і більше їх характеристик. Об'єктами уніфікації можуть бути різні вироби: матеріали, деталі, вузли, схеми, прилади, пристрої, агрегати, машини.

Уніфікація виробів супроводжується виявленням оптимальних конструкторсько-технологічних рішень та типізацією шляхом комбінування (поєднанням) найбільш вдалих конструкторсько-технологічних рішень.

Термін «уніфіковані системи моніторингу» для нашого випадку пропонуємо формулювати як поєднання систем моніторингу будівлі на етапах будівництва та експлуатації, оскільки найбільш трудомісткими та економічно затратними будуть етапи будівництва та експлуатації будівлі, і саме ці етапи розглядаються в даній статті. На нашу думку, 
з точки зору застосування моніторингу етап регенерації будівлі є менш актуальним.

Згідно 3 «ДСТУ-Н Б В.1.2-18:2016», а саме пунктом 8.4.1., Моніторинг об'єкта в нормальних умовах експлуатації проводять для виявлення небезпечних змін напруженодеформованого стану несучих конструкцій та/або грунтів основ, які потребують детального обстеження для обгрунтованої оцінки технічного стану будівель. Для етапу експлуатації можна виділити основні параметри моніторингу будівлі, такі як: міцність бетону, крен будівлі, вологість фундаментів, реакція ЗБК на вплив навантаження. Ураховуючи, що під час виконання робіт зі зведення будівельних конструкцій також необхідний періодичний контроль технічого стану виготовлених конструкцій, можна виділити основні параметри: міцність залізо-бетонних конструкцій, визначення реакції несущих конструкцій на заданих інтервалах збільшення навантаження, реєстрацію змін вологості грунтів тощо.

До технічних засобів, які можливо використовувати та уніфікувати для різних етапів моніторингу будівлі, можна віднести такі, як: інклінометри, датчики вологості, датчики температури, тензодатчики тощо. Спираючись на положення [5], можна виділити необхідну етапність проектування уніфікованих систем моніторингу, а саме:

1)розроблення проекту системи моніторингу відповідно до Т3;

2)розроблення системи спостережень для перевірки в натурі ступеню впливу нового будівництва на наявні будівлі і споруди; 3)тестування та випробування системи моніторингу. Складання відповідних актів та документів випробування;

4)монтаж системи моніторингу на об'єкті;

5)здійснення моніторингу в процесі будівництва та експлуатації протягом стабілізаційного періоду або більшого терміну, встановленого технічним завданням;

6)обробка та оперативний аналіз результатів моніторингу в режимі реального часу;

7)опрацювання результатів спостережень та підготовка відповідних висновків;

8)оцінка впливу нової будівлі і виконання робіт із їі зведення на наявні будівлі і споруди.

Для уніфікованих систем моніторингу будівлі в автоматизованому режимі роботи можливе використання тільки неруйнівних методів вимірювання. Типова блок-схема системи моніторингу матиме однаковий вигляд для різних етапів моніторингу і представлена на рис. 1.

Перспективним, на нашу думку, є розробка рішень із впровадження систем моніторингу на етапі реконструкції будівлі завдяки виконанню певних технологічних процесів, можливих лише під час виконання операцій, пов'язаних із втручанням в основні, несучі елементи та конструкції. Відомо, що реконструкцію та всі різновиди ремонтних робіт виконують фактично на етапі експлуатаціі. Під час виконання ремонтних робіт на етапі експлуатації інструментальні вимірювання є їхньою частиною і виконуються паралельно з експлуатацією без відселення мешканців або послідовно з експлуатацією з відселенням

Таблиця 1. Параметри контролю будівлі на різних етапах життєвого циклу

\begin{tabular}{|l|l|l|}
\hline \multicolumn{1}{|c|}{ Етап } & \multicolumn{1}{|c|}{ Параметри контролю } & Технічні засоби контролю та діагностики \\
\hline 1. Будівництво & $\begin{array}{l}\text { Технологічні показники } \\
\text { будівельних процесів }\end{array}$ & $\begin{array}{l}\text { Інклінометри, датчики поперечного тиску } \\
\text { на форми, датчики температури, датчики } \\
\text { вологості, акселерометри, оптичні датчики } \\
\text { вимірювання геометричних параметрів } \\
\text { конструкцій та об'єкту загалом. }\end{array}$ \\
\hline 2. Експлуатація & $\begin{array}{l}\text { Технічні показники стану } \\
\text { конструкцій та інженерних } \\
\text { систем }\end{array}$ & $\begin{array}{l}\text { Інклінометри, датчики вібрації, датчики } \\
\text { вологості, датчики температури, витратоміри, } \\
\text { датчики рівня підземних вод і т.д. }\end{array}$ \\
\hline 3. Реконструкція & $\begin{array}{l}\text { Технічні показники стану } \\
\text { аварійних конструкцій чи } \\
\text { інженерних систем }\end{array}$ & Викладене вище в пунктах № 1 і № 2. \\
\hline $\begin{array}{l}\text { 4. Регенерація або } \\
\text { ліквідація будівлі }\end{array}$ & $\begin{array}{l}\text { Прогнозування : аварійних } \\
\text { ситуації під час } \\
\text { ліквідації / технічної } \\
\text { можливості регенерації будівлі }\end{array}$ & $\begin{array}{l}\text { Інклінометри, датчики вологості, пристрої } \\
\text { визначення міцності бетону/цегляної } \\
\text { кланст, датчикикиороіії }\end{array}$ \\
\hline
\end{tabular}


мешканців. При цьому настає період соціального дискомфорту для мешканців 3 необхідністю компенсації матеріальної або моральної шкоди, що збільшує трудомісткість і вартість ремонтних робіт у цілому і інструментальних вимірювань зокрема [3]. Відомо також, що на етапі експлуатації важливим фактором впливу на технічний стан наявної забудови є вплив нового будівництва [4]. Наявність такого впливу є незаперечним фактом. Підтримання експлуатаційних властивостей і забезпечення безаварійної експлуатації будівель у зоні впливу нового будівництва є актуальним техніко-економічним завданням, що потребує достовірної інформації, отриманої інструментальними методами, для своєчасного виявлення граничних деформацій конструкцій та попередження утворення пошкоджень будівельних об'єктів. Метою забезпечення експлуатаційної придатності та безпеки прилеглих об'єктів є збереження тривалого працездатного стану оточуючих будівель, яке досягається прогнозуванням розвитку процесів ix пошкодження та своєчасною реалізацією компенсаційних заходів, що значною мірою визначається якістю виконання вимірювальних робіт. У роботі [4] проведено аналіз впливу вимірювальних робіт на експлуатаційну придатність наявних будівель. Від обсягу та періодичності отримання інформації за результатами інструментальних вимірювань залежить оперативність і адекватність прийняття рішень щодо недопущення зниження експлуатаційних характеристик об'єктів будівництва, тому їхній зміст впливає на тривалість експлуатації об'єктів.

Таким чином, використання систем моніторингу в будівництві та експлуатації в першу чергу повинно вирішувати задачу із запобіган- ня руйнації таких будівель, своєчасного виявлення відхилень від запроектованої технології будівельних процесів. Для діагностики технічного стану будівель та виявлення негативного впливу на них множини факторів слід систематизувати фактори такого впливу на будівлі [5]. Якщо довготривалі загрози можуть бути вчасно передбачені і своєчасно попереджені за рахунок нормативних заходів з експлуатації, то миттєві непередбачувані загрози (надзвичайні ситуаціï) можуть мати катастрофічні наслідки. Загрози за принципом швидкості ix появи: довготривалі загрози (поступовий розвиток дефектів та пошкоджень під впливом відомих прогнозованих загроз, наприклад, фізичне старіння); миттєві загрози з помітними проявами (швидкий розвиток надзвичайної ситуації після реалізації загрози); миттеві загрози без помітних проявів (непомітний, прихований розвиток надзвичайної ситуації після реалізації загрози). Фактори впливу на будівлю: в період експлуатації довготермінова (повзуча), викликана, як правило, старінням матеріалів, зниженням міцності. виявляється під час періодичних та планових обстежень, динаміка розвитку цього типу пошкоджень багатофакторна, прогнозування досить складне. До другого типу факторів відносяться загрози, що викликані раптовими помітними проявами, цей вид чинників не прогнозований, може бути попереджений своєчасним реагуванням на виникнення небезпеки. Такі фактори досить небезпечні, оскільки відносяться до миттєвих, але мають помітні прояви і їхній можливий вплив визначається за результатами обстежень. До третього, найбільш небезпечного типу факторів відносяться загрози, що викликані раптовими непомітними проявами, коли джерело небезпеки є випадковим

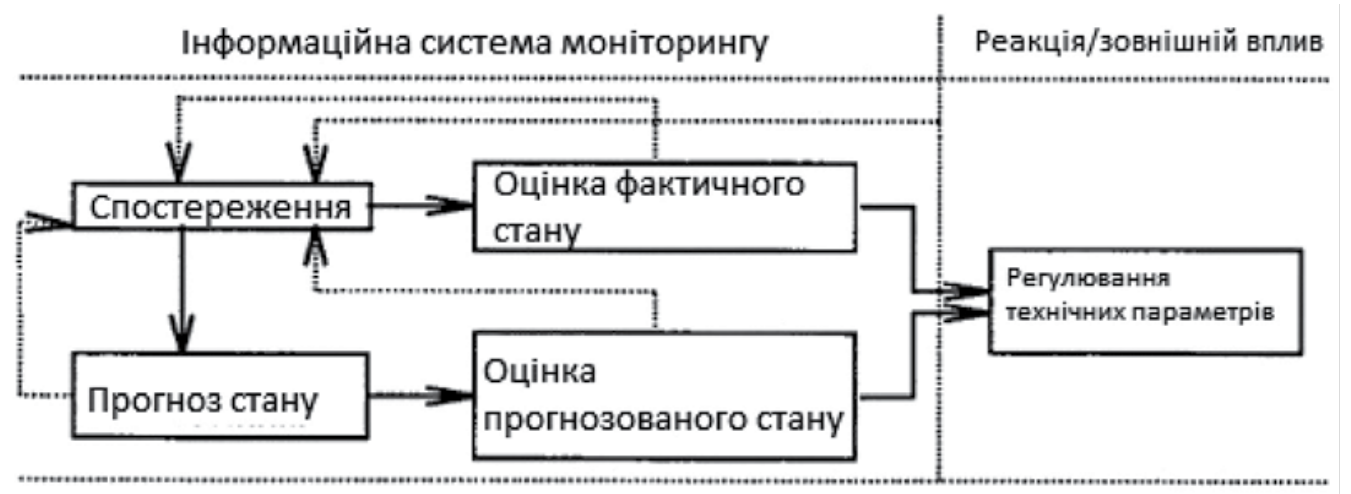

Рис. 1. Блок-схема системи моніторингу 
і конкретно не визначене. Це може бути підтоплення внаслідок аварій каналізаційних мереж, зміна рівня грунтових вод або зміна несучої здатності грунтів внаслідок впливу ущільненої забудови, вібрації від транспорту тощо.

Для уніфікації системи моніторингу, тобто поєднання систем моніторингу будівлі на етапах будівництва та експлуатації, необхідно виконати в узагальненому вигляді порівняння складу параметрів контролю будівлі на різних етапах життєвого циклу. У табл. 2 наведено результати такого узагальненого порівняння, що дає уяву про напрямки та види робіт з інструментального моніторингу.

Відповідно до табл. 2 позиції 4, 5 та 6, тобто контроль кренів будівлі, просідання будівлі, контроль зовнішніх природніх та техногенних факторів впливу необхідно виконувати як на етапі будівництва, так і на етапі експлуатації. Таким чином, системи моніторингу для забезпечення контролю цих параметрів можливі до уніфікації для етапів будівництва і експлуатації.

Саме беручи до уваги всі фактори негативного впливу на будівлю і часові межі на їх виявлення і діагностику, можливо розробити працездатні та необхідні принципи та методи для розробки та створення уніфікованих систем моніторингу технічного стану будівлі та технологічних процесів під час зведення будівлі та всього етапу експлуатації.
Висновки. Необхідним етапом для вдосконалення організації виконання технологічних рішень впровадження моніторингу протягом життєвого циклу та підвищення економічно-технічної складової частини є, зокрема, вивчення принципу поєднання та інтеграції систем моніторингу на двох етапах життєвого циклу, тобто на етапах будівництва та експлуатації.

Існують технічні та інформаційно-технологічні рішення для виконання поставленої задачі. Найбільш ефективною є інтеграція систем моніторингу під час будівництва, в системи моніторингу подальшої експлуатації будівель, уніфікація вже наявних систем моніторингу будівельних процесів, впровадження систем моніторингу на етапі регенерації/реконструкції будівлі.

Контроль кренів будівлі, просідання будівлі, контроль зовнішніх природніх та техногенних факторів впливу необхідно виконувати як на етапі будівництва, так і на етапі експлуатації. Таким чином, системи моніторингу для забезпечення контролю цих параметрів можливі до уніфікації для етапів будівництва і експлуатації.

Упровадження уніфікованих систем моніторингу з використанням нових методів фіксації та переробки даних є актуальним питанням та потребує подальшого вивчення.

Таблиця 2. Порівняння узагальненого складу параметрів контролю будівлі на різних етапах життєвого циклу

\begin{tabular}{|c|c|c|c|}
\hline \multirow{10}{*}{ 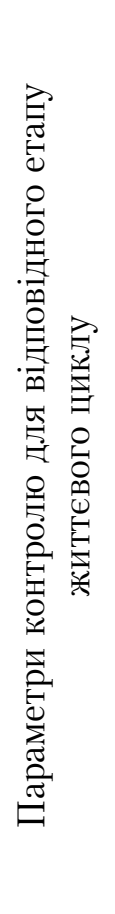 } & ( & \multicolumn{2}{|c|}{ Етап життєвого циклу } \\
\hline & № & Будівництво & Експлуатація \\
\hline & 1 & $\begin{array}{l}\text { Параметри технологічних процесів } \\
\text { в процесі будівництва }\end{array}$ & - \\
\hline & 2 & $\begin{array}{l}\text { Виконавчі знімання виконаних } \\
\text { конструкцій }\end{array}$ & - \\
\hline & 3 & $\begin{array}{l}\text { Вхідний контроль матеріалів } \\
\text { та конструкцій }\end{array}$ & - \\
\hline & 4 & Крени будівлі в процесі будівництва & Крени будівлі в процесі експлуатації \\
\hline & 5 & $\begin{array}{l}\text { Просідання будівлі } \\
\text { в процесі будівництва }\end{array}$ & Просідання будівлі в процесі експлуатації \\
\hline & 6 & $\begin{array}{l}\text { Контроль зовнішніх природніх } \\
\text { та техногенних факторів впливу } \\
\text { в процесі будівництва }\end{array}$ & $\begin{array}{l}\text { Контроль зовнішніх природніх та техногенних } \\
\text { факторів впливу в процесі експлуатації }\end{array}$ \\
\hline & 7 & - & $\begin{array}{l}\text { Контроль деформацій, що з’являються } \\
\text { в процесі експлуатації }\end{array}$ \\
\hline & 8 & - & $\begin{array}{l}\text { Контроль функціонування внутрішніх } \\
\text { інженерних мереж в процесі експлуатації }\end{array}$ \\
\hline
\end{tabular}




\title{
Jimepamypa
}

1. Уніфікація (техніка). Вікіпедія. URL : https://uk.wikipedia.org/Уніфікація_(техніка).

2. ДСТУ-Н Б В.1.2-18:2016 Настанова щодо обстеження будівель і споруд для визначення та оцінки ї технічного стану. URL : https://dbn.co.ua/load/normativy/dstu/obstezhennja_budivel_i_sporud/5-1-0-1768.

3. Чуканова Н.П. Удосконалення організаційно-технологічних рішень моніторингу технічного стану старої забудови : дис. канд. техн. наук : 05.23.08. Харків, 2020.

4. Мурасьова О.В. Удосконалення організаційно-технологічних рішень інструментального моніторингу ущільненої забудови, прилеглої до нового будівництва : дис. канд. техн. Наук : 05.23.08. Харків, 2020.

5. Немчинов Ю.И., Кендзера А.В., Бугаевский Г.Н. Динамическая паспортизация сооружений как составная часть СниПа. Будівельні конструкції : Зб. наук. праць. Київ: НДІБК, 2004. Вип.60. С. 193-198.

6. Кліменко В.З. Випробування конструкцій, обстеження та моніторинг будівель і споруд. Кондор, 2008. C. $119-128$.

7. Хавкін О.К., Калюх Ю.І., Мар'єнков М.Г., Глуховський В.П., Приємський В.Д. Моніторинг будівельних конструкцій і застосування нових державних норм ДБН В.1.1-12:2006 «Будівництво в сейсмічних районах України». Будівельні конструкції: 3б. наук. пращь. Київ : НДІБК, 2008. Вип. 69. С. 26-44.

8. Григоровський П.Є., Чуканова Н.П., Мурасьова О.В. «Аналіз факторів, що впливають на термін життя будівлі в процесі експлуатації Web of Scholar, 2018. C. 7.

\section{Unifikatsiia (tekhnika). Vikipediia. URL: https://uk.wikipedia.org/Unifikatsiia_(tekhnika),}

2. DSTU-N B V.1.2-18:2016 Nastanova shchodo obstezhennia budivel i sporud dlia vyznachennia ta otsinky yikh tekhnichnoho stanu. URL: https://dbn.co.ua/load/normativy/dstu/obstezhennja budivel i sporud/5-1-0-1768

3. Chukanova N.P. Udoskonalennia orhanizatsiino-tekhnolohichnykh rishen monitorynhu tekhnichnoho stanu staroi zabudovy: dys. kand. tekhn. nauk: 05.23 .08 Kharkiv: 2020

4. Murasova O.V. Udoskonalennia orhanizatsiino-tekhnolohichnykh rishen instrumentalnoho monitorynhu ushchilnenoi zabudovy, prylehloi do novoho budivnytstva: dys. kand. tekhn. nauk: 05.23.08 Kharkiv: 2020

5. Nemchynov Yu.I., Kendzera A.V., Buhaevskyi H.N. Dinamicheskaia pasportizatsyia sooruzhenii kak sostavnaia chast SniPa. // Budivelni konstruktsii: Zb. nauk. prats. K.: NDIBK, 2004. Vyp.60. S.193-198.

6. Klimenko V.Z. Vyprobuvannia konstruktsii, obstezhennia ta monitorynh budivel i sporud. Kondor 2008. S. $119-128$.

7. Khavkin O.K., Kaliukh Yu.I., Marienkov M.H., Hlukhovskyi V.P., Pryiemskyi V.D. Monitorynh budivelnykh konstruktsii i zastosuvannia novykh derzhavnykh norm DBN V.1.1-12:2006 «Budivnytstvo v seismichnykh raionakh Ukrainy». // Budivelni konstruktsii: Zb. nauk. prats. K.: NDIBK, 2008. Vyp.69. S. 26-44.

8. P.Ie. Hryhorovskyi, N.P. Chukanova, O.V. Murasova «Analiz faktoriv, shcho vplyvaiut na termin zhyttia budivli v protsesi ekspluatatsii» Web of Scholar, 2018. S. 7.

\section{ANALYSIS OF THE EFFICIENCY OF IMPLEMENTATION OF UNIFIED BUILDING MONITORING SYSTEMS AT THE STAGES OF CONSTRUCTION AND OPERATION}

\begin{abstract}
During the operation of buildings, the introduction of instrumental monitoring systems has recently become significantly more widespread. The introduction of these systems has become a necessity in the context of the rapid development of the use of information systems in the construction industry of Ukraine. The issue of implementing such systems both at the construction stage and at the operation stage of the building is well studied. A further step to improve the organization of technological solutions of instrumental monitoring in construction, and increase its technical and economic component, is to study organizational and technological processes, taking into account the combination and integration of monitoring systems during the life cycle of buildings during construction and operation of a building or structure. Implementation and implementation of exactly one monitoring system, which will be used during construction and operation of the building is quite relevant given the introduction of construction information technology (BIM) to model the life cycle of buildings and predict their physical deterioration. Unification of products is accompanied by the identification of optimal design and technological solutions and typification by combining (combining) the most successful design and technological solutions. It is promising to develop solutions for the implementation of monitoring systems at the stage of reconstruction of the building, due to the implementation of certain technological processes possible only during operations related to intervention in the main, load-bearing elements and structures. Reconstruction and all kinds of repair work are performed, in fact, at the stage
\end{abstract}


of operation. Unification of products is accompanied by the identification of optimal design and technological solutions and typification by combining (combining) the most successful design and technological solutions. The issue of integration of technological systems monitoring systems at the construction stage into the monitoring systems at the operation stage requires detailed study. Key words: monitoring system, organizational and technological processes, life cycle of buildings, construction information technologies.

\section{Hrihorovskyi P.Ye.}

Doctor of Technical Sciences, Senior Research Officer,

State Enterprise "Scientific Research Institute of Building Production", Kyiv

\section{Chukanova N.P.}

Head of the Department of Observation, Comprehensive Diagnostics and Experimental Design of Construction and Structures,

State Enterprise "Scientific Research Institute of Building Production”, Kyiv

Murasova O.V.

Deputy Head of Department,

State Enterprise "Scientific Research Institute of Building Production”, Kyiv

Narizhnyi V.V.

Postgraduate Student,

Kyiv National University of Construction and Architecture, Kyiv;

Engineer of the 1st category,

State Enterprise "Scientific Research Institute of Building Production”, Kyiv 